\title{
The Use of Cohesive Devices and Factors Influence Unsuccessful Coherence in Community-Based Tourism Text
}

\author{
Indah Puspitasari*, Tri Wahyu Setiawan Prasetyoningsih \\ Fakultas Ilmu Budaya, Universitas Jenderal Soedirman, Indonesia \\ indah.puspitasari@unsoed.ac.id
}

DOI: 10.20884/1.j1i.2021.12.1.3899

\begin{abstract}
Article History:
First Received:

$17 / 06 / 2021$

Final Revision:

$22 / 06 / 2021$

Available online:

\section{ABSTRACT}

$30 / 06 / 2021$

As a complex process, writing is always interesting to be discussed. One of the students' biggest problems in writing is in maintaining coherence. Coherence is a systemic model to unify some elements to become good writing. This article aims to identify the most cohesion type used by the students and factors that influence the unsuccessful coherence of the text. This is descriptive qualitative research. The data were obtained by collecting descriptive text written by thirteen English Diploma Program students. The unit of analysis in this study is a community-based tourism text which describes tourism villages in Banyumas Regency, Indonesia. The writers take Community-Based Tourism $(C B T)$ as the unit of analysis because the government right now is developing $C B T$ in many areas in Indonesia. As an important stakeholder, the University must prepare the students to write good descriptions of $C B T$. The result of this study shows most of the students use reference, reiteration, and conjunction in their writing but they have very minimal use of ellipsis, substitution, and collocation. The writers found that some of the students' sentences have successful integration, but some have not successful integration. Several factors influence unsuccessful integration. Those are students' prior knowledge, inappropriate use of cohesive devices, and illogical sequence. Finally, we can conclude that the students need more guidance and knowledge of using effective writing, cohesive devices, and logical sequence.
\end{abstract}

Keywords: cohesive devices; writing; coherence; descriptive text; English for tourism

\section{INTRODUCTION}

It has been known that writing is a complex process that requires a lot of practice. If we compare with the other skills like speaking, listening, and reading tasks, writing has always been a difficult task of all. Students sometimes may not pay attention to the coherence, event sequences, and grammatical structures that can enhance the overall writing quality. Therefore, when students write text, they do not realize that they make a lot of errors in writing especially in how to write good coherence within sentences and also a textual organization of sentences. 
Writing can cause some problems for many students of English as a foreign language (EFL). Many students' writings are not good in organization and coherence of the ideas. The students often misuse functional connectors. When the students' writings are not coherent, the reader is forced to stop and read the text again. Sometimes, the readers may give up because of frustration. Moreover, incomplete content of lexical phrases in their writings may cause incoherence of ideas and may cause confusion and also misunderstanding.

Based on the teaching experiences, the writers often come across problems from the students' writing. "I cannot follow your argument" or "I don't understand what you write" are the common comments that the teacher writes on students' papers to indicate the unacceptable text. Unfortunately, mistakes incoherence are often more difficult to handle as they involve chunks such as a series of sentences or paragraphs. The students may not know how to write effective writing, how to structure and sequence ideas with logical consistency, how to use linguistic creativity, and also how to write a text that shows coherence.

There are two different opinions about the relationship between cohesive devices and the quality of the text. One says that no relationship between the number of Cohesive Devices (CDs) and the quality of students' writings (Ghasemi, 2013). Others say that there is a highly significant relationship between the length of the text and coherence and consistency (Karadeniz, 2017). Therefore, we need more investigation into the use of CDs in students' writings because some CDs were also misused or overused (Ghasemi, 2013). Some students also prefer to use simple CDs like reference, lexical cohesion, and conjunction (Emilia et al., 2018). We often found that in some areas of students' writing is already coherent but some areas are not. (Bahaziq, 2016).

Cofffin and Donohue (2012) state that text in context or language use in context is the main unit of analysis in systemic functional linguistics (SFL). Moreover, to analyze good writing of the text, we must consider these elements; content, paragraph organization, structure, vocabulary, and mechanics (Brown, 2007). As adult learners, students often make mistakes in organizing their ideas and writing the content of the text. Some Characteristics should be considered to create good writing. They are unity, cohesion, and coherence.

Cohesive and coherence are very essential components to make organized and comprehensive texts. Coherence refers to the quality of the text. All parts fit together well and logically. Coherence also lies in the judgment of the reader; it is coherent if the reader can readily comprehend its meanings. Contextual coherence is the relation of semantic elements. For example, Andy is a student at the university. He goes to campus by bus. The text has contextual coherence 
because we understand that the meaning of "he" is Andy. The cohesive device used in this sentence is a reference (using personal pronoun).

Coherence, according to Halliday \& Hasan (2004), is a group of clauses or sentences relate to context. It is clearly explained that coherence is to unify elements in good writing. A group of clauses or sentences relate to the contexts in which there are two levels: the context of culture (ex. genre) and the context of the situation (ex. register). Coherence is established by the interaction of the writers and readers to make sense of the text based on the prior knowledge outside the text.

Cohesive devices are divided into two types, namely grammatical cohesive devices and lexical cohesive devices. Halliday and Hasan identify grammatical devices into four general categories. Those are reference, ellipsis, substitution, and conjunction. Whereas, the lexical cohesive device is a device to study all aspects of the vocabulary of the language. Lexical cohesive devices consist of two categories; reiteration and collocation. Reiteration consists of repetition, synonym, antonym, hyponym, and metonym.

Some previous studies discussed the use of cohesive devices in students' writing. First is The Use of Cohesive Devices to Achieve Coherence in the Background Section of the Students' Formal Writing (Amperawati,2011). The result of the study shows that the students can produce cohesive devices in their writing but they are quite ignoring some cohesive devices such as substitution and ellipsis. They also often misuse certain cohesive devices like reference and conjunction. They do not only make the text disorganized but also make the content incomprehensible.

The second study is The Use of Cohesive Devices in Students' Writing text (Suningsih, 2016). The result of the analysis showed that the background sections of the students' formal writing contain all kinds of cohesion devices. Those are grammatical cohesion and lexical cohesion. The third article is The Use of Cohesive Devices in Students'Argumentative Essay (Afriani,2018). The result of the study shows that the most cohesion devices used are reference $(44.3 \%)$ and followed by lexical cohesion $(39.6 \%)$, conjunction $(14.8 \%)$, substitution $(0.8 \%)$, and ellipsis $(0.5 \%)$. The use of reference is still dominating in students' writing. The last study is The Influence of Cohesive and Coherence on Text Quality: A cross-Linguistics Study of Foreign Language Learners' Written Production (Medve, V.B.,\& Takac V.P., 2013). This study aims to explore how foreign language learners use cohesion and coherence in their written production. The total sample is 90 assignments written by foreign language learners of English or German. The aim is also to identify a potential transfer of knowledge. Learners who learn both languages analyzed the number and type of CDs and the appropriateness of their usage is also assessed along with the impact on the overall quality of learners' writing. The number and type of progression 
correlate with the quality of the written composition. The results indicate that the foreign language learners' compositions are characterized by the dominant and ineffective use of simple cohesive devices and the successful learners tend to use sequential progression more often than unsuccessful learners.

From the previous researches above, we can conclude that there are incorrect cohesive devices written by the students. It causes the content incomprehensible. The students also use limited types of devices. Unfortunately, those researches did not explain factors that influence unsuccessful coherence. In this research, the writers conduct different units of analysis. The novelty of this research is on community-based tourism text and the writers also analyze factors that influence unsuccessful coherence.

Various texts are learned by the students of the English Diploma Program such as; descriptive, narrative, procedure, recount, and so on. As the students of the English Diploma Program which have a tourism concentration, they must be able to write Community-Based Tourism (CBT) text. Community based-tourism text is a text with sustainable tourism development and is usually associated with alternative tourism (Amerta,2017). The concept of community-based tourism (CBT) can be explained as the aspects of developing tourism and local communities (Lopez-Guzman et al., 2011). CBT text is a text which has a social function to describe people, objects, or something in a local community. In the English for Tourism context, CBT text describes tourist sites/attractions/villages, animals, plants, rocks, culture, people, transportation, and everything in the village. Because its function is to describe something in a tourism village, the CBT text can be written with descriptive text. We can write CBT text with these generic structures; those are identification and description. The grammar patterns used in the descriptive text are using a simple present tense and using descriptive adjectives.

CBT is chosen as the unit of analysis because the government right now is developing CBT in many areas in Indonesia. The students have to be able to describe tourist destinations well because they will take part in the tourism sector as a local guide, a tourist information officer, an officer in a travel conscious group (Kelompok Sadar Wisata / Pokdarwis), and other related jobs in the tourism sector. From a long discussion above, we draw two purposes of this research, those are to identify the most cohesion type used by the students and factors that influence unsuccessful coherence of the community-based tourism text. 


\section{MATERIALS AND METHOD}

The research design is a qualitative method. There are three types of case studies; descriptive, interpretative, and evaluative. The writers use the descriptive method which has a function to describe the use of cohesive devices in students' writing and factors influence unsuccessful coherence. The text itself is community-based tourism text. It is a text to describe tourism and the local community.

The total respondents of this research are thirteen students of English for tourism class in English Diploma Program, Universitas Jenderal Soedirman. There are two methods of collecting data. The first is a field study. In the field study, the writers obtain data from the students' writings. The second one is the library study. The library study is a method to collect relevant theories and to analyze the use of cohesive devices in students' writing and factors that influence unsuccessful coherence.

The method of analysis is descriptive qualitative. The analysis is based on the theory of Systemic Functional Linguistics by Halliday. There are more research data found in the field and will be analyzed and supported by the availability and relevancy of the theories (Sugiyono,2013). For data validation, the writers use triangulation. The triangulation approach is used since one source of data or information may be incomplete or partial.

\section{RESULTS \& DISCUSSION}

\section{The use of Cohesive Devices in Students writing}

Coherence in a paragraph is a way of making words, phrases, and sentences flow smoothly and logically from one idea to another. So that when these ideas are combined, the reader can see a consistent merging between the ideas. Therefore, maintaining paragraph coherence, the use of cohesive devices, and logical linkages between words, sentences, and paragraphs must be well constructed in students' writing.

Cohesive devices (CDs) are tools for creating a unified text meaning that can be formed from words, phrases, or sentences. CDs are divided into two types, namely grammatical cohesive devices and lexical cohesive devices. Halliday identified five categories of coherent devices that can manifest coherence in text: references, ellipsis, substitutions, lexical cohesion, and conjunctions. Whereas lexical cohesion consists of repetitions and collocations. Repetition can be a synonym, antonym, hyponym, and metonymy. Lexical cohesion is a tool for creating unity of meaning through the use of proper diction. 


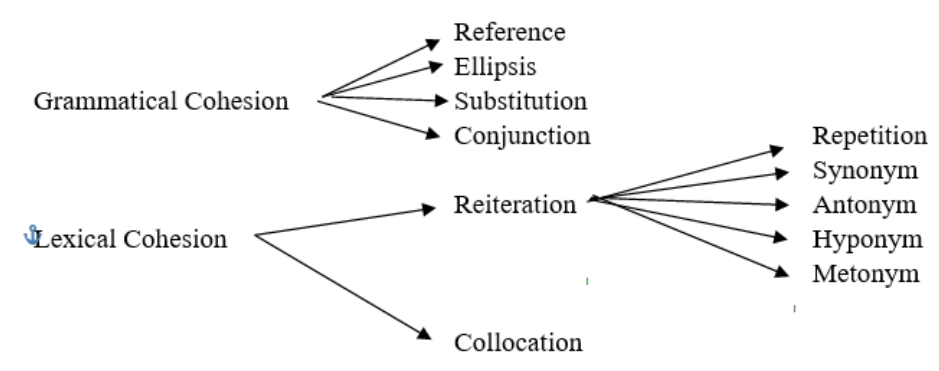

Graph 1. Cohesive Devices

(Halliday, 2000)

Grammatical cohesion is explained as the surface marking of the semantics. It links between clauses and sentences in written discourse, and between utterances and tunes in speech. Meanwhile, lexical cohesion is signaled when two words in discourse are semantically linked in some ways.

\section{Reference}

The first cohesive device is a reference. This cohesion has a special characteristic, namely, it lies in the information to be retrieved and the continuity of references that enter the discourse for the second time. Reference is usually used in semantics for the relationship between words and other things, whether factual, phenomena, or meta phenomena (Halliday and Matthiessen, 2004). There are three kinds of references:

1. Personal references are references to categories of people who take advantage of functions in speech situations. Personal references include:

a) Personal pronouns: me, him, her, you, us, them, and that, etc.

b) Personal identifier: I, mine, hers, hers, yours, yours, theirs, hers, etc.

c) Relative pronouns: who, which, whose, etc.

In this study, many students use personal references. They use a combination of personal pronouns, personal identifiers, and relative pronouns. The words are that, them, theirs, that, who, and which. The use of references in a text is very useful for maintaining contextual coherence. Examples: The use of personal pronouns in students' compositions.

Bulak Barokah Agro-tourism is a mainstay tourist destination for children because they can play while learning.

Kalisalak Tourism Village is one of the Tourism Villages in Banyumas Regency. This has increased over the last two years. 
However, the use of relative pronouns, in this case, is incorrect.

Melung Village is at the foot of the slopes of Mount Slamet and directly adjacent to the forest.

2. Demonstration reference is a reference through the location of a thing. Demonstrative references include:

a) Determinants: this, these, that, and those.

b) Demonstrative adverbs: there, here, and then.

Almost all texts analyzed by the writers use demonstrative references.

Examples: the use of demonstrative references in students' composition.

Agro-tourism Bulak Barokah is located in Langgongsari Village, Cilongok. To get there, visitors can ride a motorbike for about 10 minutes from the Cilongok traditional market.

3. Comparative references are indirect references, which describe similarities. Comparative references include:

a) Comparative adjectives: equal same, identical, different, Different, more, better, etc.

b) Comparative adverbs: differently, similarly, more, less, etc.

Some texts use comparative references. They use a variety of comparative references.

Examples: the use of comparative references in students' composition.

Interesting photo spots include the Giant Hand or God's Hand which is similar to the Pengger Yogya Pine Forest Tour.

Students experienced errors when using similar with. It must be similar to.

\section{Ellipsis}

Ellipse is a tool to create a unity of meaning through action by removing items that are usually required by the grammar. This is done because the writer assumes that the reader understands the context so that it does not need to be produced. In other words, the ellipsis can be defined as a substitution with zero. There are three types of ellipsis :

1. Nominal Ellipsis

This category requires that if the actual noun or noun phrase does not exist in the context of the discourse, it is a nominal ellipsis, as in:

These are my two bikes. I used to have three.

The word bikes have been omitted and can easily be understood or taken back out of context. There is one ellipsis in the student s' composition. 
This four-hectare area has been planted with various types of local superior fruits, such as Bawor durian, coconut, petai, and various vegetables so that it attracts tourists to visit. The livelihood of residents in Langgongsari Village is processing palm sugar. Being planted local superior commodities, not far from the garden there are several lots of buildings for processing palm sugar.

In the second sentence, the noun phrase of 'four hectares' is omitted.

2. Verbal ellipsis.

This ellipsis occurs where the verb or verb phrase is assumed, as in:

Mother: Have you finished your homework?

Andy : Yes, I have.

Andy's answer is elliptical in the sense that doing homework is understood.

3. Clausal ellipsis

Ellipsis occurs when a noun or noun phrase and an adverb phrase are omitted. yes / no questions are an example of using an ellipsis clause. Example:

Eliz : : Are you going to buy new shoes for me?

Mother : Yes.

Here mother confirms the entire clause you will buy shoes for my birthday.

Entire clauses may be omitted frequently, as in:

Andy : What grade do you get for English?

Sam $\quad: B$

All clause have been removed. Sam's answer is a clause ellipsis and not a nominal or verbal ellipsis. The writers did not find verbal substitution and clauses in the students' compositions.

\section{Substitution}

Halliday (2000) defines substitution as an act of replacing an item that is equivalent to another. There is a difference between reference and substitution. Reference has a relationship with meaning whereas substitution has a relationship with linguistic items. Substitutes have a purpose as a noun, verb, or clause. Substitution is divided into three, namely nominal substitution, verbal substitution, and clause substitution. Nominal substitution is the process of replacing a noun or noun phrase with a "one / ones" nominal substitute. Verbal substitution involves replacing a verbal verb or phrase with another verb such as "do". Clause substitution replaces clause with so or not. 
1. Nominal substitution.

Nominal substitution occurs when the element being assumed is a noun phrase or noun. Check out the example below:

Andy : Can you give me a pen?

Sam : There's one on the table.

The element of cohesion presupposes it is 'one'. The writers found most of the nominal substitutions in the students' compositions.

One of the examples:

The Highest one in Tanallum is Curug Nagasari which is 102 meters high, then

Curug Cogor which is about 35 meters high.

The word one is the supposition of a waterfall.

2. Verbal substitution.

The elements used in verbal substitution are verb phrases or verbs. The conditional element whose substitution is usually the word do and its various forms such as 'do', 'did', and 'done'.

\section{Examples:}

All kids love candy and my kids like it too.

In this study, the writers did not find verbal substitution in students' compositions.

3. Clause substitution

If the assumed element is a complete clause, then there is a clause substitution. The presupposition element that most often influences this type of substitution is 'so'.

\section{Examples:}

Employees must come to work before 7:30 am. The manager says so.

$\underline{\text { So }}$ replaces the whole sentence (i.e. the employee has to come to work before 7:30 am). In this study, the writers did not find clause substitution in students' compositions.

\section{Conjunction}

As Halliday (2000) points out "conjunctive elements are not cohesive in themselves but indirectly, under their specific meaning; they are not primarily devices for reaching the previous or next text, but they do express a specific meaning which presupposes the presence of other components in discourse".

\section{Examples:}

She goes to the bathroom after she wakes up. 
The word "after" indicates the sequence, indicating that something that is expressed in the first clause follows what is in the second clause.

1. Additive conjunctions

The source of this type of cohesion is the comparison between what was said and what has happened before. For example: similarly, likewise, in the same way, and, or.

There is additional conjunction in the student's writing. One of their writings is that Many visitors visit the cattle farm and they learn how to care for cows.

Students use the appropriate conjunction because the second clause is additional information from the first clause.

2. An adverse relationship.

The basic meaning of an adversative relationship conflict with expectations. Expectations can be derived from the context of what is being said

for example: although, though, despite, however, nevertheless.

There is an adverse association with student writing. One of their writings is that

Even though it contains sulfur, Kalibacin water is not hot.

Students use the correct conjunction because the first and second clauses of the sentence show the opposite.

3. Causal relationship.

It includes the relationship between results, reasons, and goals. For example, hence, then, so, because, consequently, therefore, for this reason. There is a causal relationship in student writing. One of their writings is

Agro-tourism Bulak Barokah which is a mainstay tourist destination for children because they can play while learning.

Students use the correct conjunctions because the first and second clauses of the sentence show a cause-and-effect relationship.

4. Temporal conjunctions.

This conjunction is a conjunction that has to do with the sequence of time. The temporal relationship can be more specific in the presence of additional components. Example: then, next, after that, just then, before, at last, finally. There are some temporal conjunctions in student writing. One of them is

Then switched to the clove area and the Albasia region. 
There is a dominant use of conjunctions in students' writing. Students mostly write complex sentences with relative clauses. The writers also found more than one conjunctions in one text.

\section{Lexical Cohesion}

Lexical cohesion has no relationship with syntax. Therefore, it is the open cohesion type and the most difficult type of cohesion to define. It is a vocabulary mover and is based on lexical relationships. There are two types of lexical cohesion:

1. Repetition is one type of lexical cohesion in the form of repetition of lexical items or the use of synonyms of several types in a reference context (Halliday, 2000). The same word in a text can have different communicative functions. Examples of using repetitions and synonyms of lexical items:

Then you can get on the bus.

Then you can take public transportation.

The use of repetition of sentences in one text:

In addition to presenting a natural landscape with a stretch of terraced rice fields,

Besides seeing the beauty of nature,

In addition, he also received seed assistance from government and private CSR agencies.

2. Collocation.

Collocations are a pair of groups of words that are usually juxtaposed. Collocation includes all types of lexical relations which do not require a referential identity and cannot be described as a type of loop. Examples: The use of verbal collocations in students' composition.

The beauty of the colorful houses of the residents is an attraction that invites many people to visit it.

For those who want to visit Kampung Pelangi Kranji, you can park your vehicle near the entrance.

Table 1. The Use of Cohesive Devices In Students' Compositions

\begin{tabular}{ccccccc}
\hline \multirow{2}{*}{ Text No } & \multicolumn{5}{c}{ The Use of Cohesive Devices } \\
\cline { 2 - 7 } & Reference & Ellipsis & Substitution & Conjunction & Reiteration & Collocation \\
\hline 1 & 5 & 0 & 1 & 5 & 1 & 2 \\
2 & 4 & 0 & 1 & 4 & 2 & 1 \\
3 & 6 & 0 & 1 & 3 & 2 & 2 \\
4 & 5 & 0 & 1 & 4 & 5 & 2 \\
5 & 5 & 0 & 1 & 3 & 3 & 1 \\
6 & 4 & 0 & 1 & 3 & 3 & 2 \\
7 & 3 & 0 & 0 & 3 & 2 & 2
\end{tabular}




\begin{tabular}{ccccccc}
8 & 5 & 0 & 0 & 2 & 3 & 1 \\
9 & 4 & 1 & 1 & 3 & 2 & 2 \\
10 & 3 & 0 & 1 & 2 & 2 & 2 \\
11 & 3 & 0 & 0 & 3 & 2 & 1 \\
12 & 4 & 0 & 1 & 2 & 2 & 1 \\
13 & 4 & 0 & 0 & 3 & 2 & 2 \\
Total & 55 & 1 & 9 & 37 & 31 & 21 \\
\hline
\end{tabular}

The text is descriptive. Text length is about 250 to 300 words. From the compositions, the writer saw that some students used limited cohesive devices. Students mostly use references, conjunctions, and repetitions but they rarely use ellipsis, substitutions, and collocations. In addition, some students wrote ideas that were not coherent, the ideas jumped from one sentence to another, so their writing did not move smoothly.

\section{Factors Influence Unsuccessful Coherence}

As mentioned earlier in this paper, coherence has a relationship with the semantic meaning of a text. Many scientists claim that the key element used by writers and readers in creating and interpreting these semantic relationships is their prior knowledge. The second important element in establishing clear semantic relationships is arranging ideas in a logical order, which is an aspect of coherence that has been emphasized in many discussions of the notion of text coherence. The existence of a cohesive relationship, achieved by using adequate lexical and grammatical cohesive devices, appears to make the text more coherent and facilitate its understanding. Many findings indicate the importance of a cohesive device in the text and its effect on the coherence of students' composition.

The writers analyze the following aspects of the composition of students. They are the overall length of the text, the cohesive devices used, and the logical sequence of ideas. Paragraph coherence is a logical sequence of ideas that creates a clear relationship between one sentence and another. A text becomes coherent when it sticks together. For each sentence in the text, there is a preceding or following sentence sequence that provides context for it. For the composition of students, the writer found that some sentences were successfully integrated, but some were not integrated successfully. Several factors contributed to the unsuccessful integration. It is students' prior knowledge, improper use of cohesive devices, and illogical sequences. These factors make the composition of students incoherent. The results of this study concluded that the use of cohesive devices has implications for incoherence in students' writing. 


\section{CONCLUSION}

Good writing ability is one the important skill which must have by the students of English for tourism. They are the agent of the tourism sector which can promote tourist destinations to the world. The writers have researched their writing and the data show that there is minimal use of cohesive devices in this case only ellipsis, substitution, and collocation. Many factors influence this condition, such as; they have limited knowledge about ellipsis, substitution, and collocation. Another data shows that the students mostly use references and conjunction in their writing. Every text has three to seven references and the most dominant reference is a personal and demonstrative reference. The conjunction which is used by the students is mostly about adversative and causal conjunction. They write the combination of three different sentences, simple, compound, and complex sentences as well. Grammatical structure is not an object of analysis in this paper but the writers also find many errors in grammatical structures that cause incoherence in their writings. Finally, the writers conclude that the students use cohesive devices to maintain coherence but they still use limited cohesive devices. The students' writing in some areas is coherent but some are not. Several factors influence unsuccessful integration or incoherence of the text. Those are students' prior knowledge, inappropriate cohesive devices, and illogical sequence. The result of the study pointed to the conclusion that the use of cohesive devices implies coherence in some areas in students' writing. The students also need more guidance and knowledge of using effective writing, cohesive devices, and logical sequence.

\section{ACKNOWLEDGEMENT}

This research is fully funded by BLU Unsoed through the scheme of competency enhancement research.

\section{REFERENCES}

Afriani. (2018). The Use of Cohesive Devices in Students' Argumentative Essays. Linguist Journal of Linguistics and Language Teaching. Vol.4 (1), July 2018.

Amerta, I. M. S. (2017). Community-based tourism development. International Journal of Social Sciences and Humanities, 1(3), 97-107. https://doi.org/10.29332/ijssh.v1n3.60.

Amperawaty, A., Warsono. (2011). The Use of Cohesive Devices to Achieve Coherence in the Background Section of the Students' Formal Writing. English Education Journal UNNES. Vol. 1 (1), November 2011.

Bahaziq, A. (2016). Cohesive Devices in Written Discourse: A Discourse Analysis of a Student's Essay Writing. English Language Teaching. https://doi.org/10.5539/elt.v9n7p112

Brown, H. D. (2007). Principles of Language Learning and Teaching. USA: Longman.

Cohen, L. (2007). Research Methods in education. New York: Routledge Taylor and Francis Group.

Coffin, C., Donohue, J. P. (2012). Academic Literacies and Systemic Functional Linguistics: How do they relate?. Journal of English for Academic Purposes. Pp 64-75. 
Crossley, S. A., Kyle, K., McNamara, D. S. (2016). The development and use of cohesive devices in L2 writing and their relations to judgments of essay quality. Journal of Second Language Writing. https://doi.org/10.1016/j.jslw.2016.01.003.

Darong, H. C. (2012). Discourse Semantics Analysis on the USA presidents' victory speeches. Unpublished Thesis: Ganesha.

Emilia, E., Habibi, N., Bangga, L. A. (2018). An analysis of cohesion of exposition texts: An Indonesian context. Indonesian Journal of Applied Linguistics. https://doi.org/10.17509/ijal.v7i3.9791.

Ghasemi, M. (2013). An investigation into the use of cohesive devices in second language writings. Theory and Practice in Language Studies. https://doi.org/10.4304/tpls.3.9.1615-1623.

Halliday, M. A. K. (2000). An introduction to functional grammar (2nd ed.). Beijing: Foreign Language Teaching and Research Press.

Halliday, M. A. K., Matthiessen, C. (2004). An introduction to functional grammar (3rd ed.). London: Oxford University Press Inc.

Hasannejad, M., Iranshahr, I., Assadi, N., Ali Kazemi, S. (2012). Substitution as a Device of Grammatical Cohesion in English Contexts. The Journal of Applied Linguistics, 5(1), 115-136.

Karadeniz, A. (2017). Cohesion and Coherence in Written Texts of Students of Faculty of Education. Journal of Education and Training Studies. https://doi.org/10.11114/jets.v5i2.1998.

López-Guzmán, T., Sánchez-Cañizares, S., \& Pavón, V. (2011). Community - based tourism in developing countries: A case study. Tourismos, 6(1), 69-84.

Ma'rifatullah, F. (2016). An Analysis of Cohesion and Coherence of a descriptive text (A Study of the Fourth Semester Students of English Education Department State Institute for Islamic Studies). IAIN Salatiga.

McNamara, D. S., Kintsch, W. (1996). Learning from texts: Effects of Prior Knowledge and Text Coherence. Discourse Processes, 22: 247-288.

Medve, V. B., \& Takač, V. P. (2013). The Influence of Cohesion and Coherence on Text Quality: A Cross-Linguistic Study of Foreign Language Learners' Written Production. September 2018, 111-131. https://doi.org/10.1007/978-3-642-35305-5 7.

Sugiyono. (2013). Metode penelitian kuantitatif, kualitatif dan R\&D. Bandung: Alfabeta. 